\title{
KARAKTERISTIK IBU HAMIL YANG MENGALAMI HIPEREMESIS GRAVIDARUM
}

\section{Yuni Kurniati}

Akademi Kebidanan Budi Mulia Palembang

\author{
Informasi Artikel : \\ Diterima : Oktober 2018 \\ Disetujui : $\quad$ Desember 2018 \\ *Korespondensi Penulis : \\ Yunikurniati80@gmail.com
}

\section{A B S T R A K}

Kematian maternal menurut World Health Organization (WHO) mencapai 585.000 jiwa setiap tahun. Faktor predisposisi yang menyebabkan hiperemesis gravidarum antara lain paritas, usia kehamilan, riwayat kehamilan, umur ibu, pekerjaan, pendidikan, riwayat penyakit ibu, psikologis, pengetahuan, dan sosial budaya. Tujuan penelitian ini untuk mengetahui karakteristik ibu hamil yang mengalami hiperemesis gravidarum di Rumah Sakit Bhayangkara Palembang tahun 2017. Dengan menggunakan metode deskriptif yaitu untuk mendeskripsikan variabel paritas, usia kehamilan, riwayat kehamilan, umur ibu, pekerjaan, dan pendidikan ibu hamil yang mengalami hiperemesis gravidarum di Rumah Sakit Bhayangkara Palembang tahun 2017. Populasi dalam penelitian ini adalah semua ibu hamil yang mengalami hiperemesis gravidarum yang pernah dirawat di Rumah Sakit Bhayangkara Palembang tahun 2017 yang berjumlah 17 orang. Sampel penelitian diambil dengan menggunakan metode Porpusive Sampling. Hasil penelitian menunjukkan paritas resiko tinggi lebih sedikit $(11,8 \%)$ dibandingkan paritas resiko rendah $(88,2 \%)$. Usia kehamilan Trimester I lebih banyak $(82,4 \%)$ dibandingkan Trimester II $(17,6 \%)$. Ibu dengan molahidatidosa dan gemeli lebih sedikit $(23,5 \%)$ dibandingkan dengan ibu yang tidak pernah mengalami molahidatidosa dan gemeli (76,5\%). Umur resiko tinggi lebih sedikit $(29,4 \%)$ dibandingkan dengan resiko rendah $(70,6 \%)$. Ibu yang bekerja lebih sedikit $(41,2 \%)$ dibandingkan dengan yang tidak bekerja $(58,8 \%)$. Ibu yang berpendidikan tinggi lebih banyak $(64,7 \%)$ dibandingkan dengan yang berpendidikan rendah $(35,3 \%)$. Diharapkan kepada petugas kesehatan dapat memberikan informasi dan penyuluhan tentang hiperemesis gravidarum dan bagi peneliti selanjutnya agar meneliti dengan metode yang berbeda serta sampel yang lebih banyak.

\section{Kata Kunci : : Hiperemesis Gravidarum.}

\section{ABSTRACT}

Maternal mortality according to the World Health Organization (WHO) reach 585,000 inhabitants every year. Predisposing factors that cause hiperemesis gravidarum, among others, gestational age, parity, maternal age, pregnancy history, employment history, education, maternal diseases, psychological, social, and cultural knowledge. The purpose of this research is to know the characteristics of pregnant women who experience hiperemesis gravidarum Bhayangkara Hospital in Palembang year 2017. By using descriptive method to describe the variable parity, gestational age, pregnancy history, age, occupation, and education of pregnant women who experience hiperemesis gravidarum Bhayangkara Hospital in Palembang year 2017. The population in this research is all the pregnant women who experience hiperemesis gravidarum ever hospitalized Bhayangkara Palembang 2017 year totalling 17 people. Research samples taken using Porpusive method of Sampling. The results showed fewer high risk parity (11.8\%) than low risk parity (88.2\%). Pregnancy Trimester I more (82.4\%) than a Trimester II (17.6\%). Mom 
with molahidatidosa and fewer gemeli (23.5\%) compared with mothers who've never experienced molahidatidosa and gemeli (76.5\%). High risk age less (29.4\%) compared to the low risk (70.6\%). Mothers work less (41.2\%) compared to not working (58.8\%). Mothers who are highly educated more (64.7\%) compared to the low educated (35.3\%). Expected to health workers can provide information and guidance about the hiperemesis gravidarum and for subsequent researchers in order to examine different methods and samples more.

\section{Keywords $\quad$ : Hyperemesis Gravidarum}

\section{PENDAHULUAN}

Hiperemesis gravidarum adalah mual muntah yang terjadi sampai umur kehamilan 20 minggu. Muntah begitu hebat dimana segala apa yang dimakan dan diminum dimuntahkan sehingga mempengaruhi keadaan umum dan pekerjaan seharihari, berat badan menurun, dan dehidrasi (Nugroho, 2010). Kehamilan merupakan hal yang fisiologis, meskipun selama kehamilan banyak hal yang berubah dalam tubuh. Kehamilan yang menyangkut nyawa ibu dan anak harus diperhatikan, sebab kehamilan bukan sekedar menyimpan anak dalam jangka waktu 9 bulan kemuduan siap dilahirkan. Namun kehamilan harus memperhatikan kesehatan ibu dan janin selama masa kehamilan dimana manyak hal patologis yang dapat dialami ibu sesuai situasi dan kondisi. Salah satu hal patologis ialah hyperemesis gravidarum.

Istilah hyperemesis gravidarum dengan gangguan metabolik yang bermakna karena mual dan muntah sehingga menyebabkan penderita HEG biasanya dirawat di rumah sakit. Etiologinya belum pasti, diduga ada hubungannya dengan paritas, hormonal, neurolgis, metabolik, stress psikologis, keracunan, dan tipe kepribadian. Insiden dari HEG adalah 0,5-10 per 1000 kehamilan. Kemungkinan terjadinya penyakit ini adalah tinggi pada orang kulit putih (16/1000 kelahiran) dan rendah pada orang kulit hitam (7/1000 kelahiran). Penyakit ini rata-rata muncul pada usia kehamilan 8-12 minggu. HEG sering disertai dengan dehidrasi (kehilangan berat badan, gangguan elektrolit dan ketosis). Sebaiknya penyebab dari mual muntah segera dievaluasi. Kemungkinan penyebab mual muntah dalam kehamilan adalah hipertiroidisme, mola hidatidosa, dan hepatitis (Fadlun, 2013).

Mual muntah merupakan hal yang umum terjadi pada awal kehamilan. Mual dan muntah biasanya terjadi pada pagi hari, oleh karena itu disebut juga morning sickness, namun tidak menutup kemungkinan juga terjadi pada siang dan malam hari. Sekitar 50-60\% kehamilan disertai dengan mual muntah, dari 360 wanita hamil, $2 \%$ diantara mengalami mual muntah dipagi hari dan sekitar $80 \%$ mengalami mual muntah sepanjang hari, kondisi ini biasanya bertahan dan mencapai puncak pada usia kehamilan 9 minggu (Fauziyah,2012).

Menurut definisi Word Health Organization (WHO) tahun 2012 memperkirakan angka kematian ibu (AKI) dari kehamilan dan persalinan di dunia mencapai 585.000 jiwa setiap tahun dan yang mengalami Hiperemesis Gravidarum sekitar 15-20\% dari seluruh jumlah ibu hamil. Sementara pada tahun 2011 diperkirakan bahwa dari $790.000 \mathrm{ibu}$ hamil yang mengalami Hiperemesis Gravidarum sekitar 10-14\% dari jumlah ibu hamil (WHO dalam Iskhakur, 2014).

Berdasarkan hasil Survei Demografi dan Kesehatan Indonesia (SDKI) pada tahun 2012, AKI di Indonesia sebesar 395 per 100.000 dan hasil survei penduduk antar sensus (PUPAS) tahun 2015 AKI di Indonesia berada pada angka 305/100.000 kelahiran hidup. Situasi ini tentu membutuhkan kerja keras untuk terus menurunkan angka kematian ibu dan bayi di Indonesia sebagai target yang ditetapkan dalam Sustainable Development Goals (SDGs) dimana target SDGs adalah angka kematian ibu hingga dibawah 70 per 100.000 kelahiran hidup pada tahun 2030 (Kemenkes RI,2017).

Angka kejadian Hiperemesis Gravidarum (HEG) di Indonesia tahun 2013 adalah 1,5-3\% dari wanita hamil. Sedangkan Hiperemesis Gravidarum (HEG) di provinsi Jawa Timur mencapai 10-15\% dari jumlah ibu hamil yang ada yaitu sebanyak 182.815 orang (Anggraeni,2015).

Hasil pengumpulan data tingkat pusat, subdirektorat kebidanan dan kandungan subdirektorat keluarga dari 325 Kabupaten/Kota menunjukkan bahwa pada tahun 2003 ibu hamil resiko tinggi dengan Hiperemesis Gravidarum (HEG) berat yang dirujuk dan mendapatkan pelayanan kesehatan lebih lanjut sebesar $20,44 \%$. Provinsi dengan persentase tertinggi adalah provinsi Sulawesi Tengah (96,53\%), dan di Yogyakarta $(76,60 \%)$ sedangkan presentase terendah adalah 
Jurnal Kebidanan : Jurnal Medical Science Ilmu Kesehatan Akademi Kebidanan Budi Mulia Palembang Volume.8 No.2, Desember 2018

provinsi Maluku Utara (3,66\%) dan Sumatera Selatan (3,81\%) (Dwiyanarosa,2013).

Laporan Dinas Kesehatan Kota Palembang Angka Kematian Ibu akibat komplikasi kehamilan dan persalinan mencapai 133/100.000 kelahiraan hidup, faktor penyebab tingginya angka kematian ibu yaitu : Pre Eklamsia Berat (31\%), Hiperemesis dalam kehamilan (23\%), ibu hamil dengan Hyperemesis Gravidarum (5,4\%), usia ibu > 35 tahun $(17,9 \%)$, ibu hamil kekurangan energi kronis $(14,3 \%)$, ibu hamil dengan anemia $(10,6 \%)$, usia ibu $<20$ tahun $(7,9 \%)$, Ketuban Pecah Dini $(7,3 \%)$, jarak kehamilan <2 tahun (4,5\%), Abortus $(4,4 \%)$ dan perdarahan $(2,0 \%)$, (Sastri, 2013).

Berdasarkan data dari Rumah Sakit Bhayangkara Palembang tahun 2016 kejadian HEG dari bulan Januari sampai bulan Desember terdapat 6 orang atau 3,1\%, dan pada tahun 2017 kejadian HEG terdapat 17 orang atau 7,8\%. Kejadian HEG merupakan masalah yang menduduki peringkat ke 4 dari 10 besar kejadian Obstetri di ruang Kebidanan Rumah Sakit Bhayangkara Palembang tahun 2017) (Laporan pembukuan Obstetri dan Ginekologi di ruang Kebidanan Rumah Sakit Bhayangkara Palembang, 2017).

Berdasarkan uraian di atas, maka peneliti tertarik untuk meneliti " Karakteristik Ibu Hamil yang Mengalami Hiperemesis Gravidarum di Rumah Sakit Bhayangkara.

\section{METODE PENELITIAN}

Penelitian ini menggunakan metode deskriptif yaitu penelitian diarahkan untuk mendeskripsikan atau menguraikan suatu keadaan di dalam suatu komunitas atau masyarakat yaitu tentang variabel paritas, usia kehamilan, riwayat kehamilan, umur ibu, pekerjaan, dan pendidikan ibu hamil yang mengalami hiperemesis gravidarum di Rumah Sakit Bhayangkara Palembang tahun 2017.

Populasi adalah keseluruhan objek penelitian atau objek yang diteliti (Notoatmodjo, 2012). Populasi dalam penelitian ini adalah semua ibu hamil yang mengalami hiperemesis gravidarum yang pernah dirawat di Rumah Sakit Bhayangkara Palembang tahun 2017 yang berjumlah 17 orang.

Sampel penelitian diambil dengan Non Random dengan menggunakan metode Purposive Sampling, yaitu pengambilan sampel berdasarkan tujuan penelitian mengenai ibu hamil yang mengalami hiperemesis gravidarum yang pernah dirawat di Rumah Sakit Bhayangkara Palembang tahun 2017 yang berjumlah 17 orang.

Penelitian ini menggunakan data sekunder, data sekunder ini diperoleh melalui medical record ibu hamil yang mengalami hiperemesis gravidarum yang pernah dirawat di Rumah Sakit Bhayangkara
Palembang pada tahun 2017 dengan instrumen yang digunakan adalah check list atau format pengambilan data.

Analisa data menggunakan analisa univariat ini untuk mengetahui distribusi frekuensi variabel penelitian yaitu paritas, usia kehamilan, riwayat kehamilan, umur ibu, pekerjaan, dan pendidikan. Penelitian ini menggunakan 17 responden dan data yang ditampilkan dalam bentuk tabel dan teks.

Data dianalisis dengan analisis univariat dengan komputerisasi (program SPSS versi 16). Analisis univariat adalah analisis yang digunakan untuk memperoleh gambaran distribusi frekuensi semua variabel penelitian (Notoatmodjo, 2012). Analisa univariat bertujuan untuk mendapatkan gambaran dengan melihat distribusi frekuensi dan persentase dari tiap variabel yaitu guna mendapatkan gambaran variabel berupa paritas, usia kehamilan, riwayat kehamilan, umur ibu, pekerjaan, dan pendidikan. Data ini akan dianalisis secara deskriptif pada karakteristik ibu hamil yang mengalami hiperemesis gravidarum di Rumah Sakit Bhayangkara Palembang tahun 2017.

Analisa data menggunakan analisa univariat ini untuk mengetahui distribusi frekuensi variabel penelitian yaitu paritas, usia kehamilan, riwayat kehamilan, umur ibu, pekerjaan, dan pendidikan. Penelitian ini menggunakan 17 responden dan data yang ditampilkan dalam bentuk tabel dan teks.

\section{HASIL PENELITIAN}

\section{a. Paritas}

Tabel 1 Distribusi Frekuensi Paritas Ibu Hamil yang Mengalami

\begin{tabular}{cccc}
\hline No & Paritas & Frekuensi & Persentase \\
\hline 1 & Resiko Tinggi & 2 & $11,8 \%$ \\
\hline 2 & Resiko Rendah & 15 & $88,2 \%$ \\
\hline & Total & 17 & $100 \%$ \\
\hline
\end{tabular}

Tabel 1 diatas menunjukkan bahwa responden dengan paritas resiko tinggi $(11,8 \%)$ lebih kecil dibandingkan dengan responden paritas resiko rendah $(88,2 \%)$.

\section{b. Usia Kehamilan}

Tabel 2 Distribusi Frekuensi Usia Kehamilan Ibu Hamil yang Mengalami Hiperemesis Gravidarum

\begin{tabular}{cccc}
\hline No & $\begin{array}{c}\text { Usia } \\
\text { Kehamilan }\end{array}$ & Frekuensi & Persentase \\
\hline 1 & Trimester I & 14 & $82,4 \%$ \\
\hline 2 & Trimester II & 3 & $17,6 \%$ \\
\hline & Total & 17 & $100 \%$ \\
\hline
\end{tabular}


Jurnal Kebidanan : Jurnal Medical Science Ilmu Kesehatan Akademi Kebidanan Budi Mulia Palembang Volume.8 No.2, Desember 2018

Tabel 2 diatas menunjukkan bahwa responden dengan usia kehamilan trimester I $(82,4 \%)$ lebih besar dibandingkan dengan responden usia kehamilan trimester II $(17,6 \%)$.

\section{c. Riwayat Kehamilan}

Tabel 3 Distribusi Frekuensi Riwayat Kehamilan Ibu Hamil yang Mengalami Hiperemesis Gravidarum

\begin{tabular}{clcc}
\hline No & $\begin{array}{c}\text { Riwayat } \\
\text { Kehamilan }\end{array}$ & Frekuensi & Persentase \\
\hline 1 & Ya & 4 & $23,5 \%$ \\
\hline 2 & Tidak & 13 & $76,5 \%$ \\
\hline & Total & 17 & $100 \%$ \\
\hline
\end{tabular}

Tabel 3 menunjukkan bahwa responden dengan riwayat kehamilan mengalami molahidatidosa atau gemeli $(23,5 \%)$ lebih kecil dibandingkan dengan responden yang tidak ada riwayat kehamilan mengalami molahidatidosa atau gemeli $(76,5 \%)$.

\section{d. Umur Ibu}

Tabel 4 Distribusi Frekuensi Umur Ibu Hamil yang Mengalami Hiperemesis Gravidarum

\begin{tabular}{cccc}
\hline No & Umur Ibu & Frekuensi & Persentase \\
\hline 1 & Resiko Tinggi & 5 & $29,4 \%$ \\
\hline 2 & Resiko Rendah & 12 & 70,65 \\
\hline & Total & 17 & $100 \%$
\end{tabular}

Tabel 4 diatas menunjukkan bahwa responden dengan umur resiko tinggi $(29,4 \%)$ lebih kecil dibandingkan dengan responden umur resiko rendah $(70,6 \%)$.

\section{e. Pekerjaan}

Tabel 5 Distribusi Frekuensi Pekerjaan Ibu Hamil yang Mengalami Hiperemesis Gravidarum

\begin{tabular}{cccc}
\hline No & Pekerjaan & Frekuensi & Persentase \\
\hline 1 & Bekerja & 7 & $41,2 \%$ \\
\hline 2 & Tidak Bekerja & 10 & $58,8 \%$ \\
\hline & Total & 17 & $100 \%$ \\
\hline
\end{tabular}

Tabel 5 diatas menunjukkan bahwa responden yang bekerja $(41,2 \%)$ lebih kecil dibandingkan dengan responden yang tidak bekerja $(58,8 \%)$.

\section{f. Pendidikan}

Tabel 6 Distribusi Frekuensi Pendidikan Ibu Hamil yang Mengalami Hiperemesis Gravidarum

\begin{tabular}{clcc}
\hline No & Pendidikan & Frekuensi & Persentase \\
\hline 1 & $\begin{array}{l}\text { Pendidikan } \\
\text { Tinggi }\end{array}$ & 11 & 64,7 \\
\hline 2 & $\begin{array}{l}\text { Pendidikan } \\
\text { Rendah }\end{array}$ & 6 & 35,3 \\
\hline \multicolumn{2}{c}{ Total } & 17 & 100 \\
\hline
\end{tabular}

Tabel 6 diatas menunjukkan bahwa responden yang berpendidikan tinggi $(64,7 \%)$ lebih banyak dibandingkan dengan responden yang berpendidikan rendah $(35,3 \%)$.

\section{PEMBAHASAN}

\section{a. Paritas}

Paritas adalah jumlah anak yang telah dilahirkan oleh seorang ibu baik lahir hidup maupun lahir mati. Paritas dikelompokkan menjadi 2 (dua) kategori, yaitu : paritas resiko tinggi (jika anak > 3 orang anak) dan paritas resiko rendah (jika anak $\leq 3$ orang anak).

Mual dan muntah terjadi $60 \%-80 \%$ wanita dengan kehamilan pertama (primigravida) dan $40 \%-60 \%$ pada wanita yang sudah pernah hamil lebih dari satu kali (multigravida). Jumlah kehamilan 2 - 3 (multi) merupakan paritas yang aman ditinjau dari sudut kematian maternal. Hal ini dikarenakan persiapan fisik ibu dalam menghadapi kehamilan sudah lebih matang dibandingkan dengan kehamilan pertama ibu (Wiknjosastro,2007).

Seperti halnya dengan umur, paritas merupakan salah satu faktor yang berperan terhadap tingginya kecenderungan terjadinya hiperemesis gravidarum sebagai salah satu keadaan yang berakibat patologi bagi ibu dan janin yang dikandungnya. Hiperemesis gravidarum lebih banyak terjadi pada wanita yang baru pertama kali hamil dan pada wanita dengan paritas tinggi seperti ibu yang sudah mempunyai 4 orang anak. Paritas 2-3 merupakan kelompok resiko rendah terhadap terjadinya hiperemesis gravidarum (Runiari, 2010).

Hasil analisis univariat menunjukkan bahwa responden dengan paritas resiko tinggi $(11,8 \%)$ lebih sedikit dibandingkan dengan responden paritas resiko rendah $(88,2 \%)$ di 
Rumah Sakit Bhayangkara Palembang tahun 2017. Hal ini bisa terjadi karena ibu yang sudah memiliki anak 2 dan tiga orang memiliki kesibukan yang banyak dalam melayani kebutuhan suami, anak dan keluarga terdekatnya. Ada juga ibu yang bekerja dan harus juga menyelesaikan pekerjaan rumah dan sekaligus mengurus anak-anaknya setelah pulang bekerja. Hal ini menyebabkan walaupun ia tergolong paritas dengan resiko rendah ia tetap dapat mengalami hiperemesis gravidarum.

Berdasarkan penelitian Ridwan (2007) hiperemesis gravidarum lebih banyak terjadi pada ibu yang baru pertama kali hamil dibandingkan dengan ibu yang sudah mengalami kehamilan sebelumnya. Hal ini tidak terlepas oleh karena faktor psikologis yakni takut terhadap tanggung jawab sebagai ibu, ini dapat menyebabkan konflik mental yang dapat memperberat mual muntah pada saat kehamilan.

Berdasarkan penelitian yang dilakukan oleh Helen (2007), hiperemesis gravidarum lebih banyak terjadi pada wanita yang baru pertama kali hamil dan paritas tinggi seperti ibu yang sudah mengalami kehamilan yang keempat. Hal ini tidak terlepas oleh karena faktor psikologis yakni takut terhadap tanggung jawab sebagai ibu, bila ibu tersebut tidak sanggup lagi mengurus anak-anaknya. Ini dapat menyebabkan konflik mental yang dapat memperberat mual dan muntah.

Berdasarkan penelitian yang dilakukan oleh Wijiati (2011), Hasil analisis univariat menunjukkan bahwa jumlah yang mempunyai 1 dan > 3 anak lebih banyak yaitu 58\% dibandingkan jumlah ibu yang mempunyai 2-3 anak yaitu $42 \%$, hasil analisis bivariat menunjukkan pada kelompok responden dengan resiko tinggi mengalami hiperemesis gravidarum lebih sedikit $(28,4 \%)$ dibanding dengan tidak mengalami hiperemesis gravidarum $(71,6 \%)$ sedangkan pada kelompok responden yang resiko rendah jumlah ibu yang mengalami hiperemesis gravidarum lebih sedikit $(14,4 \%)$ dibandingkaan yang tidak mengalami hiperemesis gravidarum $(85,6 \%)$.

Berdasarkan penelitian yang dilakukan oleh Novi Rakhmwati (2011), pada analisis univariat jumlah responden yang termasuk paritas tinggi sebanyak 92 orang $(49,7 \%)$ dan termasuk paritas rendah sebanyak 93 orang (50,3\%), pada analisis bivariat dengan 92 responden yang termasuk paritas tinggi terdapat 44 orang $(47,8 \%)$ ibu hamil yang mengalami hiperemesis gravidarum serta dari 93 responden yang termasuk paritas rendah terdapat 17 orang
$(18,3 \%)$ yang mengalami hiperemesis gravidarum, dari hasil uji chi square didapatkan $\mathrm{p}$ value $=0,000<0,05$ hal ini menunjukkan ada hubungan yang bermakna.

Hasil penelitian di Rumah Sakit Bhayangkara ini menunjukkan bahwa hiperemesis gravidarum lebih sedikit jumlahnya terjadi pada ibu yang telah mempunyai anak lebih dari 3 yaitu 4 dan 5 orang anak. Hal ini dapat terjadi sesuai dengan teori yang menerangkan bahwa ibu yang memiliki anak lebih dari 3 seperti 4 dan 5 memiliki kecemasan terhadap peran dan tanggung jawab yang lebih besar dan juga kekhawatiran terhadap kecukupan gizi dan pendidikan anaknya kelak. Secara teori pada kehamilan 2-3 (multi) merupakan paritas yang aman ditinjau dari sudut kematian maternal. Hal ini dikarenakan persiapan fisik dan mental ibu dalam menghadapi kehamilan sudah lebih matang dibandingkan dengan kehamilan pertama ibu. Tetapi untuk anak lebih dari 3 kembali memberikan efek kurang nyaman pada kondisi fisik dan mental ibu sehingga kejadian hyperemesis gravidarum dapat dialami ibu hamil tersebut.

Sehingga dari hasil penelitian ini ibu yang memiliki paritas dengan resiko rendah lebih banyak mengalami hiperemesis gravidarum dibandingkan ibu dengan paritas resiko tinggi.

\section{b. Usia Kehamilan}

Usia kehamilan adalah usia kandungan dihitung dari hari pertama dari haid terakhir. Usia kehamilan dikelompokkan menjadi 2 (dua) kategori, yaitu : kategori trimester I (jika usia kehamilan ibu $\leq 12$ minggu) dan kategori trimester II (jika usia kehamilan ibu $>12$ minggu).

Mual dan muntah adalah gejala yang wajar dan sering terdapat pada trimester I $\left(\begin{array}{lll}0 & -12\end{array}\right.$ minggu). Mual biasanya terjadi pada pagi hari tetapi dapat pula timbul setiap saat dan malam hari. Gejala-gejala ini kurang lebih terjadi pada usia kehamilan 6 minggu setelah hari pertama haid terakhir dan berlangsung selama kurang lebih 10 minggu (Wiknjosastro, 2007).

Hasil analisis univariat menunjukkan bahwa responden dengan usia kehamilan trimester I $(82,4 \%)$ lebih banyak dibandingkan dengan responden usia kehamilan trimester II $(17,6 \%)$ di Rumah Sakit Bhayangkara Palembang tahun 2017.

Berdasarkan penelitian yang dilakukan oleh Dania (2008), hiperemesis gravidarum lebih 
banyak terjadi pada wanita dengan usia kehamilan trimester I dibandingkan pada wanita dengan usia kehamilan trimester II. Hal ini disebabkan karena perubahan pengaruh hormonal dan psikis pada saat usia kehamilan trimester I.

Hasil penelitian di Rumah Sakit Bhayangkara ini menunjukkan bahwa hiperemesis gravidarum lebih banyak terjadi pada ibu dengan usia kehamilan trimester I dibandingkan dengan ibu usia kehamilan trimester II. Hal ini dikarenakan mual-muntah adalah gejala yang wajar dan sering terjadi pada trimester I (0-12 minggu), gejala-gejala ini kurang lebih terjadi pada usia kehamilan 6 minggu setelah hari pertama haid terakhir dan berlangsung selama kurang lebih 10 minggu akibat meningkatnya kadar estrogen di dalam tubuh saat memasuki usia kehamilan trimester I serta adanya perubahan indra penciuman dan perasaan pada awal kehamilan.

\section{c. Riwayat Kehamilan}

Riwayat kehamilan dikelompokkan menjadi 2 (dua) kategori, yaitu : kategori Ya (jika ada riwayat kehamilan mengalami molahidatidosa atau gemeli) dan kategori Tidak (jika tidak ada riwayat kehamilan mengalami molahidatidosa atau gemeli).

Faktor presdisposisi yang sering dikemukakan adalah pada molahidatidosa dan kehamilan ganda. Frekuensi yang tinggi pada molahidatidosa dan kehamilan ganda menimbulkan dugaan bahwa faktor hormon memegang peranan karena pada kedua keadaan tersebut hormon khorionik gonadotropin dibentuk berlebihan (Prawirohardjo, 2005).

Hasil analisis univariat menunjukkan bahwa responden dengan riwayat mengalami molahidatidosa atau gemeli $(23,5 \%)$ lebih sedikit dibandingkan dengan responden yang tidak ada riwayat kehamilan mengalami molahidatidosa dan gemeli $(76,5 \%)$ di Rumah Sakit Bhayangkara Palembang tahun 2017.

Berdasarkan penelitian yang dilakukan oleh Dania (2008), hiperemesis gravidarum lebih banyak terjadi pada wanita yang tidak ada riwayat kehamilan mengalami molahidatidosa atau gemeli dibandingkan pada wanita dengan riwayat kehamilan mengalami molahidatidosa atau gemeli. Hal ini disebabkan pengaruh ketidakseimbangan hormon pada kehamilan.

Hasil penelitian di Rumah Sakit Bhayangkara ini menunjukkan bahwa hiperemesis gravidarum lebih banyak terjadi pada ibu yang tidak pernah mengalami riwayat molahidatidosa dan gemeli dibandingkan dengan ibu yang pernah mengalami riwayat molahidatidosa dan gemeli. Hal ini dikarenakan kemungkinan adanya riwayat kehamilan hiperemesis gravidarum pada kehamilan sebelumya selain riwayat kehamilan molahidatidosa atau gemeli dimana pengaruh hormon estrogen yang dihasilkan saat kehamilan menjadi meningkat sehingga menyebabkan mual dan muntah.

\section{d. Umur Ibu}

Umur ibu adalah waktu lamanya ibu hidup yang dihitung berdasarkan tanggal lahir sampai saat penelitian ini dilaksanakan yang tercantum dalam status ibu. Umur ibu dikelompokkan menjadi 2 (dua) kategori, yaitu : umur resiko tinggi (jika umur ibu < 20 tahun dan $>35$ tahun) dan umur resiko rendah (jika umur ibu 20 - 35 tahun).

Penyebab dari hiperemesis gravidarum belum diketahui secara pasti, namun hamil pada usia muda merupakan salah satu faktor penyebabnya dan berhubungan dengan kehamilan pertama dan kehamilan ganda dan usia dibawah 24 tahun. Wanita dengan riwayat mual pada kehamilan sebelumnya dan mereka yang mengalami obesitas (kegemukan) juga mengalami peningkatan resiko hiperemesis gravidarum (Anwar, 2010).

Hamil pada usia muda merupakan salah satu faktor penyebab terjadinya hiperemesis gravidarum. Dalam kurun reproduksi sehat dikenal bahwa usia aman untuk kehamilan dan persalinan adalah 20 - 30 tahun. Kematian maternal pada wanita hamil dan melahirkan pada usia dibawah 20 tahun adalah 2 - 5 kali lebih tinggi daripada kematian maternal yang terjadi pada 20 - 29 tahun. Kematian maternal meningkat kembali setelah usia 30 - 35 tahun (Wiknjosastro, 2007).

Hasil analisis univariat menunjukkan bahwa responden dengan umur resiko tinggi $(29,4 \%)$ lebih sedikit dibandingkan dengan responden umur resiko rendah $(70,6 \%)$ di Rumah Sakit Bhayangkara Palembang tahun 2017.

Berdasarkan penelitian yang dilakukan oleh Wahidudin (2007), hiperemesis gravidarum dibawah umur 24 tahun lebih disebabkan karena belum cukupnya kematangan fisik, mental dan fungsi sosial dari calon ibu. Hal ini mempengaruhi emosi ibu sehingga terjadi konflik mental yang membuat nafsu ibu kurang 
makan. Sedangkan hiperemesis gravidarum yang terjadi diatas umur 35 tahun juga tidak lepas dari faktor psikologis yang disebabkan karena tidak menginginkan kehamilannya lagi sehingga merasa tertekan dan menimbulkan stres. Hal ini yang memicu terjadinya mual dan muntah pada ibu.

Berdasarkan penelitian yang dilakukan oleh Wijiati (2011), Hasil analisis univariat menunjukkan bahwa jumlah ibu yang berumur < 24 tahun lebih sedikit yaitu 35,1 orang dibandingkan jumlah ibu yang berumur $\geq 24$ tahun yaitu $64,9 \%$, hasil analisis bivariat menunjukkan pada kelompok responden umur resiko tinggi diperoleh jumlah ibu yang mengalami hiperemesis gravidarum lebih sedikit $(27,3 \%)$ dibandingkan yang tidak mengalami hiperemesis gravidarum $(72,7 \%)$, dari hasil uji chi square menunjukkan $\mathrm{p}$ value $=0,026<$ nilai $\alpha=0,05$. Hal ini menujukkan ada hubungan yang bermakna.

Berdasarkan penelitian yang dilakukan oleh Novi Rakhmwati (2011), pada analisis univariat jumlah responden yang termasuk umur resiko tinggi sebanyak 53 orang $(28,6 \%)$ dan yang termasuk umur resiko rendah sebanyak 132 orang $(71,4 \%)$, pada analisis bivariat dengan 53 responden yang termasuk umur resiko tinggi terdapat 24 orang $(45,3 \%)$ ibu hamil yang mengalami hiperemesis gravidarum serta dari 132 responden yang termasuk umur resiko rendah terdapat 37 orang $(28,0 \%)$ yang mengalami hiperemesis gravidarum, dari hasil uji chi square didapatkan $p$ value $=0,037<0,05$ hal ini menunjukkan ada hubungan yang bermakna.

Hasil penelitian di Rumah Sakit Bhayangkara ini menunjukkan bahwa hiperemesis gravidarum lebih banyak terjadi pada ibu dengan umur resiko rendah dibandingkan dengan ibu umur resiko tinggi. Hal ini dikarenakan pengaruh ketidaksiapan ibu untuk menerima tanggung jawab sebagai ibu, serta pengaruh ketidakseimbangan hormon pada kehamilan. Faktor-faktor lain yang menyebabkan hiperemesis gravidarum selain faktor umur ibu juga dapat mempengaruhi kejadian hiperemesis gravidarum. Sehingga dalam peneilitian ini ibu dengan umur tergolong resiko rendah lebih banyak mengalami hiperemesis gravidarum.

\section{e. Pekerjaan}

Pekerjaan adalah aktivitas yang dilakukan seseorang dirumah atau tempat lain secara rutin atau berkala dengan tujuan mendapatkan uang.
Pekerjaan dikelompokkan menjadi 2 (dua) kategori, yaitu kategori bekerja (jika ibu melakukan aktifitas yang menghasilkan uang) dan kategori tidak bekerja (jika ibu tidak bekerja misalnya ibu rumah tangga).

Faktor psikologik memegang peranan yang penting pada penyakit ini, walaupun hubungannya dengan terjadinya hiperemesis gravidarum belum diketahui dengan pasti. Rumah tangga yang retak, kehilangan pekerjaan, takut terhadap tanggung jawab sebagai ibu dapat menyebabkan konflik mental yang dapat memperberat mual dan muntah, sebagai ekspresi tidak sadar terhadap kehamilan (Wiknjosastro, 2007).

Penyebab utama terjadinya hiperemesis gravidarum seperti cemas dengan kehamilan dan persalinan, sehingga dapat memicu stres ibu hamil yang dapat memperberat mual dan muntah sebagai pelarian kesukaran hidup (Sarwono, 2005).

Hasil analisis univariat menunjukkan bahwa responden yang bekerja $(41,2 \%)$ lebih sedikit dibandingkan dengan responden yang tidak bekerja $(58,8 \%)$ di Rumah Sakit Bhayangkara Palembang tahun 2017.

Berdasarkan penelitian Satyanegara (2007) ibu hamil yang bekerja berpengaruh terhadap kondisi kesehatannya karena di tengah-tengah ibu sibuk bekerja, ibu hamil juga harus mempersiapkan fisik dan mental dalam proses kehamilan. Keadaan ini dapat mempengaruhi emosi ibu sehingga kondisi ini dapat mempengaruhi psikologis ibu yang dapat mengakibatkan hiperemesis gravidarum.

Hasil penelitian di Rumah Sakit Bhayangkara ini menunjukkan bahwa hiperemesis gravidarum lebih banyak terjadi pada ibu yang tidak bekerja dibandingkan dengan ibu yang bekerja. Hal ini dikarenakan beban kerja ibu di rumah yang terlalu berat yang membuat ibu kurang nafsu makan sehingga asam lambung meningkat dapat pula dikarenakan kurangnya kesiapan fisik dan mental sehingga menyebabkan kondisi emosional ibu menjadi labil. Sebagai ibu rumah tangga yang tidak menghasilkan uang dan harus mengatur keuangan agar semuanya terpenuhi juga dapat memicu kestabilan emosional ibu. Sehingga kejadian hiperemesis gravidarum juga dialami ibu hamil yang tidak bekerja dalam hal ini sebagai ibu rumah tangga biasa. 


\section{f. Pendidikan}

Pendidikan adalah suatu kegiatan atau proses pelajaran untuk mengembangkan atau meningkatkan pengetahuan tertentu sehingga sasaran pendidikan itu dapat berdiri sendiri. Pendidikan dikelompokkan menjadi 2 (dua) kategori, yaitu : pendidikan tinggi (jika pendidikan ibu $\geq$ SLTA / sederajat) dan pendidikan rendah (jika pendidikan ibu < SLTA / sederajat).

Hasil analisis univariat menunjukkan bahwa responden yang berpendidikan tinggi $(64,7 \%)$ lebih banyak dibandingkan dengan responden yang berpendidikan rendah $(35,3 \%)$ di Rumah Sakit Bhayangkara Palembang tahun 2017.

Berdasarkan penelitian Iriyani (2007) pengetahuan dapat dipengaruhi seseorang termasuk juga perilaku terhadap pola hidup dan memotivasi untuk siap berperan termasuk juga perilaku kesehatan, makin tinggi pendidikan seseorang makin mudah menerima informasi sehingga banyak pula pengetahuan yang dimiliki. Sebaliknya makin rendah atau kurang pendidikan seseorang akan menghambat perkembangan sikap terhadap nilai yang baru diperhatikan.

Hasil penelitian di Rumah Sakit Bhayangkara ini menunjukkan bahwa hiperemesis gravidarum lebih banyak terjadi pada ibu berpendidikan tinggi dibandingkan dengan ibu berpendidikan rendah. Hal ini dikarenakan akibat informasi yang diterima terlalu banyak sehingga ibu terlalu bersifat protektif atau berlebihan terhadap kondisi kehamilannya sehingga menimbulkan kecemasan yang berlebihan pada diri ibu itu sendiri. Ibu yang tergolong berpendidikan rendah juga dapat mengalami hiperemesis gravidarum dikarenakan faktor lain seperti emosional ibu yang kurang stabil dan dapat juga karena perubahan hormon pada saat hamil. Pendidikan yang rendah dapat mengurangi kematangan emosional ibu dalam menghadapi kehamilannya.

\section{KESIMPULAN}

1. Ibu dengan paritas resiko tinggi $(11,8 \%)$ lebih sedikit dibandingkan dengan ibu paritas resiko rendah $(88,2 \%)$ di Rumah Sakit Bhayangkara Palembang tahun 2017.

2. Ibu dengan usia kehamilan trimester I $(82,4 \%)$ lebih banyak dibandingkan dengan ibu usia kehamilan trimester II $(17,6 \%)$ di Rumah Sakit Bhayangkara Palembang tahun 2017.
3. Ibu dengan riwayat kehamilan mengalami molahidatidosa atau gemeli $(23,5 \%)$ lebih sedikit dibandingkan dengan ibu yang tidak ada riwayat kehamilan mengalami molahidatidosa atau gemeli (76,5\%) di Rumah Sakit Bhayangkara Palembang tahun 2017.

4. Ibu dengan umur resiko tinggi $(29,4 \%)$ lebih sedikit dibandingkan dengan ibu umur resiko rendah $(70,6 \%)$ di Rumah Sakit Bhayangkara Palembang tahun 2017.

5. Ibu yang bekerja $(41,2 \%)$ lebih sedikit dibandingkan dengan ibu yang tidak bekerja $(58,8 \%)$ di Rumah Sakit Bhayangkara Palembang tahun 2017.

6. Ibu yang berpendidikan tinggi $(64,7 \%)$ lebih banyak dibandingkan dengan ibu yang berpendidikan rendah $(35,3 \%)$ di Rumah Sakit Bhayangkara Palembang tahun 2017.

\section{Saran}

\section{Bagi Penulis}

Bagi peneliti selanjutnya agar meneliti variabel yang lainnya dengan metode yang berbeda serta sampel yang lebih banyak.

\section{Bagi Institusi Pendidikan Kesehatan}

Hasil penelitian ini dapat digunakan sebagai bahan referensi (perpustakaan) khususnya bagi mahasiswi Akademi Kebidanan Budi Mulia dalam memberikan informasi dan pengetahuan tentang hiperemesis gravidarum.

\section{Bagi Tempat Penelitian}

Bagi pihak Rumah Sakit Bhayangkara Palembang diharapkan hasil penelitian ini dapat dijadikan sebagai masukkan untuk memberikan informasi dan penyuluhan tentang hiperemesis gravidarum.

\section{DAFTAR PUSTAKA}

Anggraeni, A. C. 2015. Asuhan Gizi Nutritional Care Process. Yogyakarta: Graha Ilmu.

Dinkes Kota Palembang. 2012. Profil Kesehatan Kota Palembang 2012. (www.dinkes.Palembang.go.id). (diakses tanggal 17 September 2018).

Fadlun. 2013. Asuhan Kebidanan Patologis. Jakarta: Salemba Medika.

Fauziah. Yulia. 2012. Obstetri Patologi Untuk Mahasiswa Kebidanan Dan Keperawatan. Yogyakarta: Nuha Medika. 
Jurnal Kebidanan : Jurnal Medical Science Ilmu Kesehatan Akademi Kebidanan Budi Mulia Palembang Volume.8 No.2, Desember 2018

Hidayat, Alimul. 2010. Metode Penelitian Kebidanan Dan Teknik Analisis Data. Jakarta : Salemba Medika.

(http://digilib.ummus.ac.id/files/disk1/113/jtptummu s-9dl-minervarid-5611-1-babi-pdf/), diakses 17 September 2018.

(http://ilmu-asuhankebidanan.blogspot.com/2009/07/hiperemesis -gravidarum.html), diakses 17 September 2018.

(http://www.alhamsyah.com/blog/kesehatan/muntah -berlebihan-saat-kehamilan), diakses 24 Agustus 2018.

(http://www.klikdokter.com/medisaz/read/2010/07/0 5/22/hiperemesis-gravidarum), diakses 10 Oktober 2018.

(http://www.riskesdas.litbang.depkes.go.id/laporan2 $\underline{010}$ ), diakses 17 September 2018.

Kemenkes RI, 2017. Profil Kesehatan Indonesia Tahun 2015. Jakarta.

Lochart, Anita. 2014. Asuhan Kebidanan Kehamilan Fisiologi dan Patologi. Jakarta: Bina Rupa Aksara.

Manuaba, Ida Ayu Chandranita. 2008. Ilmu Kebidanan, Penyakit Kandungan, Dan KB Untuk Pendidikan Bidan. Jakarta : EGC.

Manuaba, Ida Ayu Chandranita. 2009. Buku Ajar Patologi Obstetri Untuk Mahasiswa Kebidanan. Jakarta : EGC.

Manuaba, Ida Bagus Gede. 2007. Pengantar Kuliah Obstetri. Jakarta : EGC.

Notoatmodjo, Soekidjo. 2010. Metodologi Penelitian Kesehatan. Jakarta : Rineka Cipta.

Nugroho, Taufan. 2010. Kasus Emergency Kebidanan Untuk Kebidanan Dan Keperawatan. Yogyakarta : Nuha Medika.

Prawirohardjo, Sarwono. 2013. Ilmu Kebidanan. Jakarta : Yayasan Bina Pustaka.

Profil Kesehatan Kota Palembang, 2013. (http//www.academia.edu/7117185/PROFIL_ Dinkes.com) di akses tanggal 09 September 2018.
Rekam Medik dan Profil Rs Bhayangkara Palembang, 2017.

Rukiyah, Ali Yeyeh. 2010. Asuhan Kebidanan IV. Jakarta : Trans Info Media.

Runiari. 2010. Asuhan Keperawatan Pada Klien Dengan Hyperemesis Gravidarum, Penerapan Konsep Dan Teori Keperawatan. Jakarta : Salemba Medika.

Saifuddin, Abdul Bari. 2009. Ilmu Kebidanan (Kematian Ibu Dan Perinatal). Jakarta : Bina Pustaka.

Sulistyawati, Ari. 2010. Asuhan Kebidanan Pada Masa Kehamilan. Jakarta : Salemba Medika.

Wiknjosastro, Hanifa. 2007. Ilmu Kebidanan. Jakarta: Yayasan Bina Pustaka Sarwono Prawirohardjo. 
